\title{
PHYSICO CHEMICAL ANALYSIS OF SOIL IN THE DEFFERENT REGION OF CHANDRAPUR
}

\author{
PRASHANT S. UTALE \\ Department of Chemistry, Shri Shivaji Science College, Nagpur, Maharashtra \\ (India). \\ Email: psutale@gmail.com
}

\begin{abstract}
:
A soil test determine the soil's nutrient supplying capacity by mixing soil during the analysis with a very strong extracting solution (often an acid or a combination of acids). The soil reacts with the extracting solution, releasing some of the nutrients. As soil supplies most of the mineral nutrition for higher plants through the plant's root system, the extracted nutrient concentration was evaluated based on research that relates plant utilization to soil nutrient concentration.
\end{abstract}

Keywords:

\section{INTRODUCTION:}

Environmental chemistry is the scientific study of the chemical and biochemical phenomena that occurs in natural places. It should not be confused with green chemistry, which seeks to reduce potential pollution at its source. It can be defined as the study of sources, reaction, transport, effects and fates of chemical species in the air, soil and water environment.

The soil is not a mass of dead debris, merely resulting from the physical, chemical and biological weathering of rocks, it is a more or less homogeneous system which has resulted from the decomposition of plant and animal remains. Soil is used to grow most of the world's food and much of its fiber. The world's mushrooms human population imposes increasing and increasing pressure on farmer to produce more food each year. The quality of human diet is determined by the hectares of soil available per person and the quality and management of various soils to produce food. Soil quality is a measure of the ability of a soil to carry out particular ecological function. Soil quality reflects a combination of chemical, physical and biological properties. Anthropogenic activities such as indiscriminate use of pesticides and fertilizers, disposal of industrial and domestic effluents, municipal sewage sludge and soil waste cause undesirable changes in the physical, chemical and biological parameters of soil[1].

Soil acts as thin layer of earth's crust which serves as a natural medium for the growth of plants and it is the unconsolidated mineral matter influenced by genetic and environmental factors. Soil differs from the parent material in the morphological, physical, chemical and biological properties.

All the soil properties and the value of the soil $\mathrm{pH}$ can widely differ in reliance on soil type, topography, climate, vegetation and anthropogenic activity, because all these factors influence spatial variability of the observed soil type. Application of fertilizers is one of the cause of the soil acidification. The acidification of soil by $\mathrm{N}$ fertilizer is caused by transformation of nitrogen in soil. The uptake of $\mathrm{N}$ as ammonium in the crop also contributes to soil acidification.

Bhandara district is an administrative district in the state of Maharashtra in India. Bhandara has a mixed economy with agriculture, industries and forest resources. Bhandara is known for its large production of rice. Tumsar, a tehsil town is a noted rice market. Bhandara town is also known as "BRASS CITY" owing to the presence of a large 
brass products industry. By checking the soil nutrients (n, p, k) and etc. we can find out the nutrient value of soil and necessary action can be taken to increase the soil fertility and it also helps to select the crops suitable for that soil. We can also check the microbial flora in the soil such as nitrogen fixing bacteria, phosphate solubilizing bacteria etc. to decrease the use of chemical fertilizer.

\section{MATERIAL AND METHOD:}

Study area:- Chandrapur district is one of the $>$ nine districts of vidarbha region of

Maharashtra state and in chandrapur district nagbhid and bramhapuri are two of the 15 taluka's and this are the part of bramhapuri sub $>$ division. it is a district in the Nagpur Division in the Indian state of Maharashtra .

The Chandrapur district is located in the far east of Maharashtra state. It is part of Nagpur division. $>$ The district lies the in the eastern part of vidarbha region. The chandrapur district is located $>$ between $19.30^{\prime} \mathrm{N}$ and $20.45^{\prime} \mathrm{N}$ latitude and at $78.46{ }^{9} \mathrm{E}$ longitude. The district is surrounded by Bhandara and Nagpur districts at its northern $>$ side, Wardha and Yavatmal districts at its western side, Gadchiroli district on the eastern $>$ side and Adilabad district of Telangana State on the southern side. In the Survey of India degree sheet, it falls in NOS $55 \mathrm{LF}$ and $561 \mathrm{M}$.

Soil type:- The soil of the Bramhapuri and Nagbhid taluka in Chandrapur dist. can be classified as red, brown, sandy and black cotton soil. The black soil covers most of the pans of the deccan trap, sandy and silty soil occurs along the alluvial plains of the rivers. The soils are black, medium fertile and superior to that of the upland areas.

\section{COLLECTION OF SOIL SAMPLE:}

A) PURPOSE OF COLLECTION OF SOIL SAMPLE

$>$ To study the soil types

$>$ To evaluate the fertility of soil

$>$ To know the genesis of soil

$>$ To study the microbial flora of soil SAMPLING TECHNIQUE: the method of sampling depends largely on the purpose for which it is to be collected. in the case of manures and crop experiments sampling technique is quite different. When general fertility is to be found numbers of samples to he collected vary according to size of plot. However 15.20 samples/hectare are advised for such experimental purpose. For field crops such as jowar, wheat etc. sample $15-30 \mathrm{~cm}$ is to be taken.

\section{PROCEDURE:}

First divide the field according to slope, depth, texture, management \& cropping pattern. After demarcation of field into uniform portion each of this must be sampled separately.

Then divide each unit in two parts. Draw the zigzag line having about 8 to 10 corners on both the sides of middle line that it will cover the whole area.

Where the crops has been planted collect the soil samples between the lines.

Do not sample unusual area. Avoid area recently fertilized, marshy spots, near trees, compost heaps etc.

Use proper sampling tools like auger, soil tube. Spade (phawada) or trowel (khurpi).

Before taking the sample, scrape away surface litter or any stone etc. Collect the soil sample from 10 to 20 spots in the field depending upon the area. At each corner of the zigzag Jine take the sample by auger at the depth of $20-30 \mathrm{cms}$ or with the help of trowel \& spade by digging "V'• shaped hole upto plough depth. Then cut out uniform thick $2 \mathrm{cms}$ slice of soil from bottom to top of exposed soil surface. Collect the sample on the blade or in your hands and place it in clean buckets.

$>$ Collected, the sample from the uniform area into this same bucket.

$>$ Pour the soil from the bucket on a piece of clean paper or cloth $\&$ mixed thoroughly. .

$>$ Discarded by quartering, excess of soil and collected about $1 \mathrm{Kg}$ of soil. 
$>$ To quarter the sample, mixed well. divided into four equal parts \& rejected opposite quarters. Mixed the remaining two portions $\&$ repeat the procedure as many times as necessary to arrive at the desired quantity of sample.

$>$ If the sample was found wet or moist, it was dried in the shade before putting into plastic bags.

$>$ Filled the sample into plastic bag \& the plastic bag was put into cloth bag.

$>$ Filled out the information sheet completely $\&$ packed inside the sample bag $\&$ put it one outside the bag.(3)

\section{BIOLOGICAL PARAMETER}

\section{Nitrogen fixing bacteria:}

In another part of the cycle, he process of Nitrogen fixation constantly puts additional nitrogen into biological circulation. This was carried out by free-living nitrogen-fixing bacteria in the soil or water such as $\underline{\text { Azotobacter }}$ or by those that live in close symbiosis with leguminous plants, such as rhizobia, these bacteria colonies in nodules they create on the roots of peas, beans, and related species. these are able to convert nitrogen from the atmosphere into nitrogencontaining organic substances.

PROCEDURE: Nitrogen fixing bacteria like rhizobiun and azotobacter can be isolated from soil by using selective medias. For isolation of rhizobia, selective Rhizobium media is used and for Azotobactor selective media Yeast Mannitol agar is used. Soil suspension are prepared and inoculated on the sterile petriplates in appropriate media and is incubated for $48 \mathrm{hrs}$, After incubation period the petriplates are observed, shiny milky colour (as shown in fig 1) as $\mathrm{s}$ are observed are of nitrogen fixing bacteria.(20)

\section{Phosphate solubalizing bacteria:}

Phosphorus (P) was one of the essential macronutrients for plants and is applied to soil in the formed of phosphate fertilizers. However, a large portion 0th soluble inorganic phosphate which is applied to the soil as chemicalfertilizer is inunobilized rapidly and beeolnes unavailable to plants. ${ }^{2}$ Currently, the tuain purpose in managing soil phosphorus is to optitnize ecop production and tninituize $\mathrm{P}$ loss froni soils. PSB have attracted the attention agriculturists as soil inoculums to improve the plant growth and yield. When PSB is used with rock phosphate. It can save about $50 \%$ of the crop requirement of phosphatic fertilizer.

Many different strains of these 'bacteria have been identified as PSB, including Pantoea agglomerans $\quad(\mathrm{P} 5), \quad \underline{\text { Microbaclerium }}$ laevaniformans (P7) and Pseudomonas putida (P13) strains are highly efficient insoluble phosphate solubilizers.

Many different strains of these bacteria have been identified as PSB, including Pantoea agglomerans (P5), Microbacterium laevaniformans (P7) and

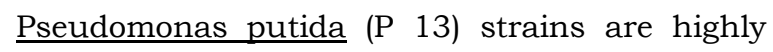
efficient insoluble phosphate solubilizers.

PROCEDURE: For PSB an selective media Pikovskayas agar was used. The soil suspension is inoculated on sterile petriplates having media and is incubated for 48 hrs. After incubation period the plates are observed, colonies with clear zone are observed ( as shown in figure 2). (21)

\section{RESULT \& DISCUSSION}

\section{ELECTRICAL CONDUCTIVITY}

The electrical conductivity of soils varies depending on the amount of moisture held by soil particles. Sands have a low conductivity, silts have a medium conductivity, and clays have a high conductivity. Consequently, EC correlates strongly to soil particle size and texture.

$\underline{\text { EC Effect }\left(\mathrm{dS} \mathrm{m}^{-1}\right)}$

$<1$ - No deleterious effect on crop

1-2 - Critical for salt sensitive crops 2-3 - Critical for salt tolerant crops

$>3$ - Injurious to most crop

\section{$\mathbf{P h}$}

The availability of some plant nutrients was greatly affected by soil $\mathrm{pH}$. The "ideal" soil $\mathrm{pH}$ is 
close to neutral, and neutral soils are considered to fall within a range from a slightly acidic $\mathrm{pH}$ of 6.5 to slightly alkaline $\mathrm{pH}$ of 7.5 . It has been determined that most plant nutrients are optimally available to plants within this 6.5 to 7.5 $\mathrm{pH}$ range, plus this range of $\mathrm{pH}$ is generally very compatible to plant root growth.

\section{Categories of soil pH values:}

$\begin{array}{ll}\text { Soil pH } & \text { : Interpretation } \\ <5.0 & : \text { Strongly Acidic } \\ 5.1-6-5 & : \text { Slightly Acidic } \\ 6.6-7.5 & : \text { Neutral } \\ -8.0 & : \text { Mild Alkaline } \\ >8.0 & : \text { Strongly Alkaline }\end{array}$

\section{ORGANIC CARBON}

Plant productivity was linked closely to organic matter (Bauer and Black, 1994).

Consequently, landscapes with variable organic matter usually show variations in productivity. Plants growing in well-aerated soils are less stressed by drought or excess water. In soils with less compaction, plant roots can penetrate and flourish more readily.

High organic matter increases productivity and, in turn, high productivity increases organic matter.

\section{Limits:}

Low $<0.5 \%$

Medium0.5-0.75\%

High $>0.75 \%$

\section{REFERENCES:}

“wlabs.com”. wlabs.ccn. Retrieved 2012-11-08.

Abdulmajeed Mlitnn. Impact of Treated Wastewater on Some Physicochemical Parameters Soil and Its Fungal Content International Journal of Environmental Science and Development. 2015; 6:5.

AM Shivanna, G Nagendrappa. Chemical Analysis of Soil Samples to Evaluate the Soil Fertility Status of Selected Command Areas of Threc Tanks in Tiptur Taluka of
Karnataka, India Journal of Applied Chemistry

Anu Upadhyaya SK, Bajpai Avinash. Seasonal Analysis of Soil Sediment of Shahpura Lake of Bhopal (M.P.). International Journal of Environmental Science and Development, October. 2010; I :4.

AOAC, (1995). Official Methods ofAnalysis. 16 th Cdn. Association of Official Analytical Chemists, Washington, DC.

Black, C.A. (1965) Methods of soil analysis Part I Am. Soc. Agron. Inc. Publi. Madison Wisconsin USA.

Carl J. Rosen. "Lead in the Home Garden and Urban Soil Environment"

Chesnin, L. and Yien, C.N. (1951). Proc.Soil Sci. Soc. Am. 15 : 149 Curr. Sci. 66 : 314316.Bardsley, C.S. and Lancaster, 11. J.P. (1960). Proc. Soil Sci. soc. Am. 24 : 265.

Joel OF, Amajuyoyi CA. Determination of Selected Physicochemical Parameters and Heavy Metals in a Drilling Cutting Dump Site at Ezeogwu- Owaza, Nigeria, J Appl. Sci. Environ. Manage. 2009; 13(2):27-31.

Jordan-Meille, Rubæk, G. H.; Ehlert, P. a. L; Genot, V.; Hofman, G.; Goulding, K.; Recknagel, J.; Provolo, G.; Barraclough, P. (2012-12-01). "An overview of fertilizer-P recommendations in Europe: soil testing, calibration and fertilizer recommendations", Soil Use and Management. 28 419-435. Doi: $10.1111 / \mathrm{j} .1475-2743.2012 .00453 .1$. ISSN1475-2743.

Kiran G. Chaudhari Studies of the physicochemical parameters of soil samples Advances in Applied Science Research 2013; 4(6):246248

Koenig, R.A. and Johnson, C.R. (1942). Colorirnetric determination of biological materials Ind. Eng. Chem. Analyt. Edn. 14 : 155-156.

Lindsay, W.L. and Norvell, W.A. (1978). Proc, Soil Sci. Soc. Am. 42 : 421 - 


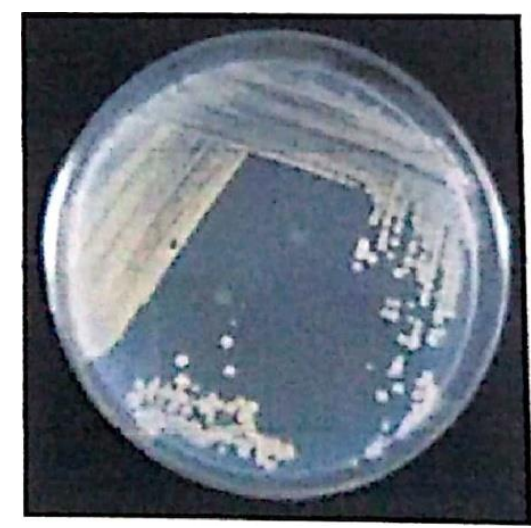

Fig 1:- colonies of nitrogen fixing bacteria

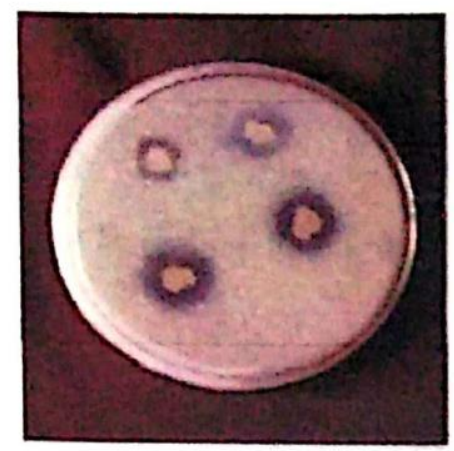

Fig 2:- colonies of phosphate solubalizing bacteria

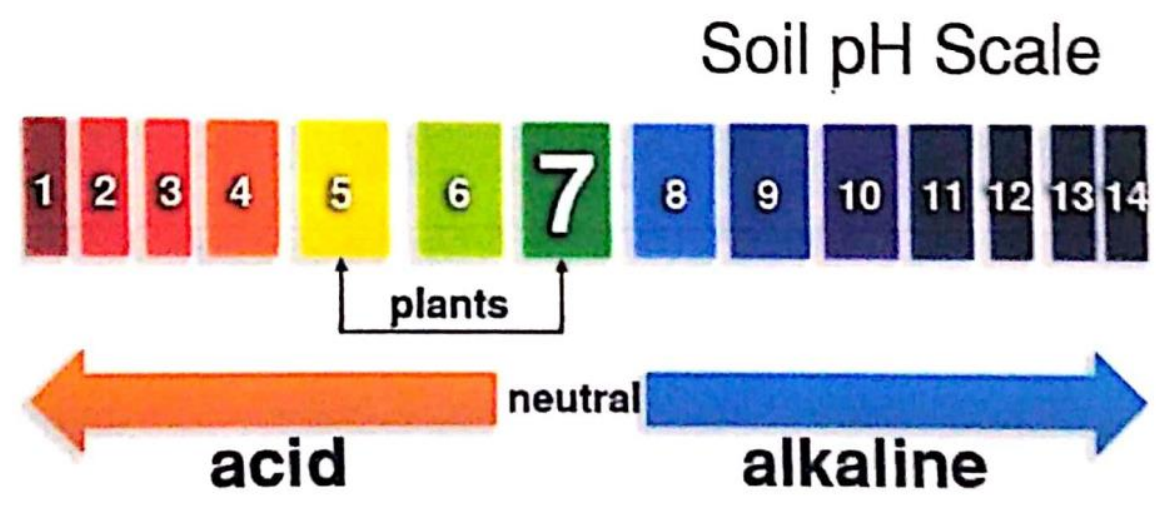

Fig 3:- Ph scale 